ORIGINAL SCIENTIFIC PAPER

316.2(470)"18/19"

316.3:303

DOI:10.5937/ZRFFP45-9242

Petr E. TSARKov ${ }^{1}$

RUSSIAN RESEARCH INSTITUTE FOR CULTURAL

AND NATURAL HERITAGE

Moscow

\title{
PROPRIETARY METHODOLOGY OF SOCIOLOGICAL TEXT ANALYSIS
}

ABSTRACT. This article considers experience of applying such sociological methods as content analysis and information-goal analysis to studying the heritage of representatives of pre-revolution Russian social conception (P. I. Novgorodtsev, B. P. Vysheslavtsev, I. A. Ilyin and N. N. Alekseev). The author applies methodological model of semantic and structural analysis based on combination of classical qualitative and quantitative content analysis and information-goal analysis.

KEY WORDS: content analysis, methodological model, semantic analysis, structural analysis.

petrcarkov@gmail.com

This paper was submitted on 11 March 2015 and accepted for publication at the meeting of the Editorial Board held on 8 October 2015. 
The analytical method proposed by Petr Tsarkov is most effective for researching texts characterized by vague conceptive framework and rendering polysemantic and complex ideas (literary, publicistic, social and philosophical, social and scientific texts etc.). Moreover, this methodology may be successfully applied to analysing musical pieces and works of art, including architectural works.

In the works representing P. I. Novgorodtsev's school the concept of social ideal is not represented as a comprehensive theory. This is attributable to the fact that in early Modernity ${ }^{2}$ social sciences were still taking their shape and their philosophical prerequisites were controversial.

Therefore one can speak only of the totality of conceptions of the authors under consideration and of separate theoretical constructs which have furthermore evolved since the publication of the book On Social Ideal in 1917, a key one for P. I. Novgorodtsev's school, up to the beginning of the 1950s. Theoretical statements belonging to the notion of the social ideal stand out from this totality, and the entire concept of the social ideal is being formed as a complex.

This research is a content analysis of the sources including monographs and articles by P. I. Novgorodtsev and his disciples B. P. Vysheslavtsev, I. A. Ilyin and N. N. Alekseev, which enables to empirically check the integrity of conceptual framework and the realism of goals and means for implementing the social ideal.

In the course of the research the author analyzed the contents of sixty-five sources -24 articles and 41 monographs. These texts contain information belonging to the notion of the social ideal.

Analysis of the sources has been performed in two stages applying the methodology based on classical content analysis on the one hand and the information-goal analysis of texts developed by T. M. Dridze (1984) on the other hand. Analysing method by T. M. Dridze is most effective for studies involving vague conceptive framework and rendering polysemantic and complex ideas (publicistic, social and philosophical texts etc. ).

2 The term Modernity (Modern era) is used to designate historical period at the turn of the XX century. In a broad sense Modernity (Modern era) is the epoch following the Middle Ages. In a strict sense, used by the author of the thesis, Modernity is a period from 1910 to 1960 . At that historical period social sciences were still taking their shape and their philosophical prerequisites were controversial. 
The model similar to the one developed by T. M. Dridze is used at the second stage of the research. It is formed considering the following assumptions:

- Stylistic similarity of texts devoted to the social ideal created by the representatives of P. I. Novgorodtsev's school;

- Identity of conceptual framework for interpretation of the social ideal in the works by P. I. Novgorodtsev, B. P. Vysheslavtsev, A. Ilyin and N. N. Alekseev (which is verified at the first stage of the research).

The method of classical quantitative content analysis (Orlova, 2013) is used at the first stage of the research. The aim of this stage of analysis is to empirically check the integrity of theoretical framework of the social ideal concept developed by the authors under consideration.

The research begins with the content analysis of texts containing the authors' conceptions of the social ideal. Content analysis is a qualitative and quantitative method of text research that possesses peculiar procedures of sampling material formalization (Gotlib, 2005). Therefore, sense-bearing units reflecting the totality of views of the authors under consideration are singled out first. Being expressed in the text by definite terms and typical word groups, information, appraisals and notions constitute the sampling units for the analysis. Thus, content analysis starts with logical and linguistic procedures. After that appropriate mathematical tools are developed for quantitative analysis ofsense bearing units found.

Theoretical subject of the first stage of the research is the concept of the social ideal; empirical subject is the representation of this concept in monographs and articles by P. I. Novgorodtsev and the representatives of his school - B. P. Vysheslavtsev, I. A. Ilyin and N. N. Alekseev. An ideal model based on several key categories substantiating its social significance defines the theoretical subject. The author regards these key categories, serving as the measure of the social ideal, as the subject of the first stage of the research.

Seven key dimensions are singled out within such theoretical context: economic, political, legal (establishing the principles of social organization), philosophical, religious, scientific and aesthetical (establishing the principle of world outlook) ${ }^{3}$, which may

3 Substantiation of these measurements as necessary and sufficient for institutional organization of social life, ref. (Eisenstadt, 1999, pp. 173-225). 
be considered sufficient to empirically check the integrity of the social ideal concept represented in the works by P. I. Novgorodtsev and represent the subject of the research in the entirety required to reach the goals of the research.

To perform the first stage of the research the author formulated the following research tasks:

1) To give the definition of economic, political, legal, philosophical, religious, scientific and aesthetical dimensions of the social ideal;

2) To single out the most frequently repeating categories which characterize the social ideal in the analyzed texts;

3) To single out identical categories with all the four authors under consideration.

Let us consider the scheme of analysis applied at the second stage. As was mentioned above, here the model containing the elements of both classical content analysis and information-goal analysis developed by T. M. Dridze is applied.

As the subject of the analysis the concept of the social ideal developed by the representatives of P. I. Novgorodtsev's philosophical school is considered. The author accepts the viewpoint of T. M. Dridze who regards such notions as subject, author's intention and goal of message as equal categories.

Content analysis is performed in line with the specially defined topic which, according to a number of westerns sociologists, is one of the most productive and applicable units of analysis, especially forresearching ideology, axiological and metaphysical concepts etc. (Holsti, 1968, pp. 646-648).

Any topic contains some concrete ideas called Theses by T. M. Dridze. A thesis is an opinion or a definition given without any substantiation and verification. Components of the Goaltaxon may correlate to the theses. Goal is distinguished from Thesis by its orientation at performing a certain action. A goal presumes singling out taxons that are the components of method and task categories. The action constituting the goal is itemized according to the number of tasks. The tasks belong to a definite goal and are formulated as the stages of reaching this goal in line with the common guideline and logical order.

Method is a category pointing at the process of completing tasks and reaching a goal. The content of methods for the purpose of major theoretical constructs by P. I. Novgorodtsev, B. P. Vysh- 
eslavtsev, I. A. Ilyin and N. N. Alekseev, their conformance to the goals announced and effectiveness of their application are the factors on which depends the possibility of implementing the social ideal.

Example is another category used for the research, and it mutually depends on the Thesis category:an example is required to substantiate a thesis. It is built up and singled out in correlation with such key categories of analysis as Goal, Task and Method.

The methodology used at the second stage of the research is semantic and structural analysis. It has been developed in line with the theory of T. M. Dridze according to which the text should be split into extracts and categories in order to define and understand its connotations. This methodological framework comprises four sublevels:

1) The text is split into parts according to topics; semantic (connotational) modules are defined.

2) The number of sense-making words most important for the research and used in the text is calculated and the correlation of frequency of their use is measured.

3) Text semantic analysis itself (analysis of sense of the basic textcomponents). This level of the research is of particular importance as it presupposes finding and estimating module-wise the distribution of words and word groups that are most important for the research as well as basic loads of the modules. It is followed by excluding modules without any message.

4) Connections between the modules (both evident and latent) are identified. Analysis of connections between the modules is performed in order to expose their mutual correspondence.

Analytical work is performed according to the above-mentioned methodological framework. At the first stage of the research the sources containing the authors' conceptions of the social ideal were analysed -forty-one monographs and twenty-four articles. The work has been performed using the above-mentioned methodology for the first stage.

In line with the tasks stated in the research program, the categorical model was developed (see Scheme 1).

Despite the similarity of conceptualization of the social ideal notion with all the four thinkers, as a model it may be represented by two levels: a relative social ideal (optimum at the given period) 
and an absolute social ideal (which serves as a guideline and a final goal directing social development).

SCHEME 1

SOCIAL IDEAL IN THE WORKS OF P. I. NOVGORODTSEV'S SCHOOL REPRESENTATIVES

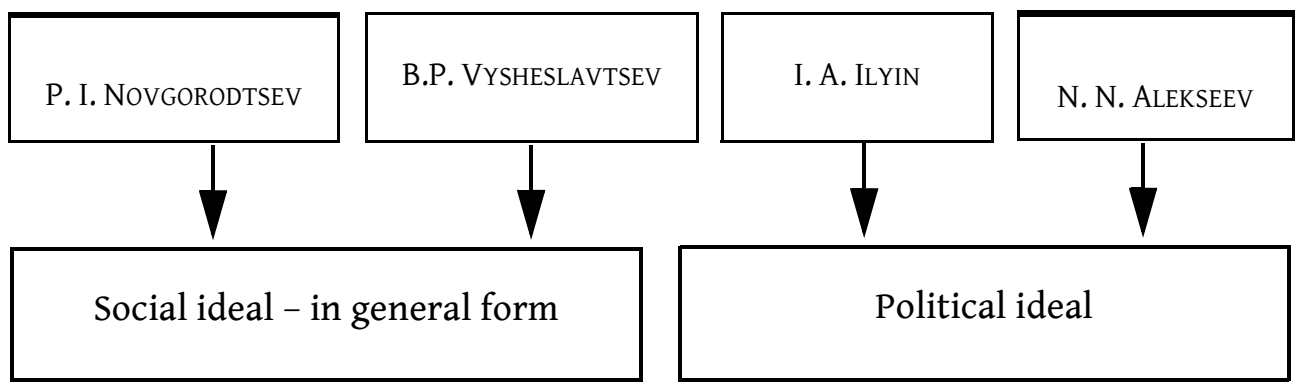

Between these two levels the authors imply the ongoing historical process understood as permanent progress in the course of which a relative ideal gradually approaches an absolute one. It should be stressed one more time that the views of representatives of this school overlap (see Fig. 1).

The stress made while conceptualization of the ideal enables to single out two levels by convention. Political ideal mostly developed by I. A. Ilyin and N. N. Alekseev corresponds to the relative social ideal. Absolute social ideal correlates to the category of social ideal in general form the stress on which was put upon in the works by P. I. Novgorodtsev and B. P. Vysheslavtsev.

Thus the categorical model was by convention split into two directions according to the stresses put in the theories of the authors under consideration - social ideal in general form and political ideal. Developing the categorical model the author proceeded from an ideal and typical conception where social space is represented by seven institutional dimensions required to represent the social ideal with sufficient theoretical entirety. Each of the directions is divided into seven dimensions where organization of the socially important activity is represented by economic, political and legal changes, and institutionalized world outlook - by religious, philosophical, aesthetical and scientific dimensions. To single out these key dimensions it is required to check up the completeness of theoretical framework of the social ideal concept represented in the works of the authors under consideration. 


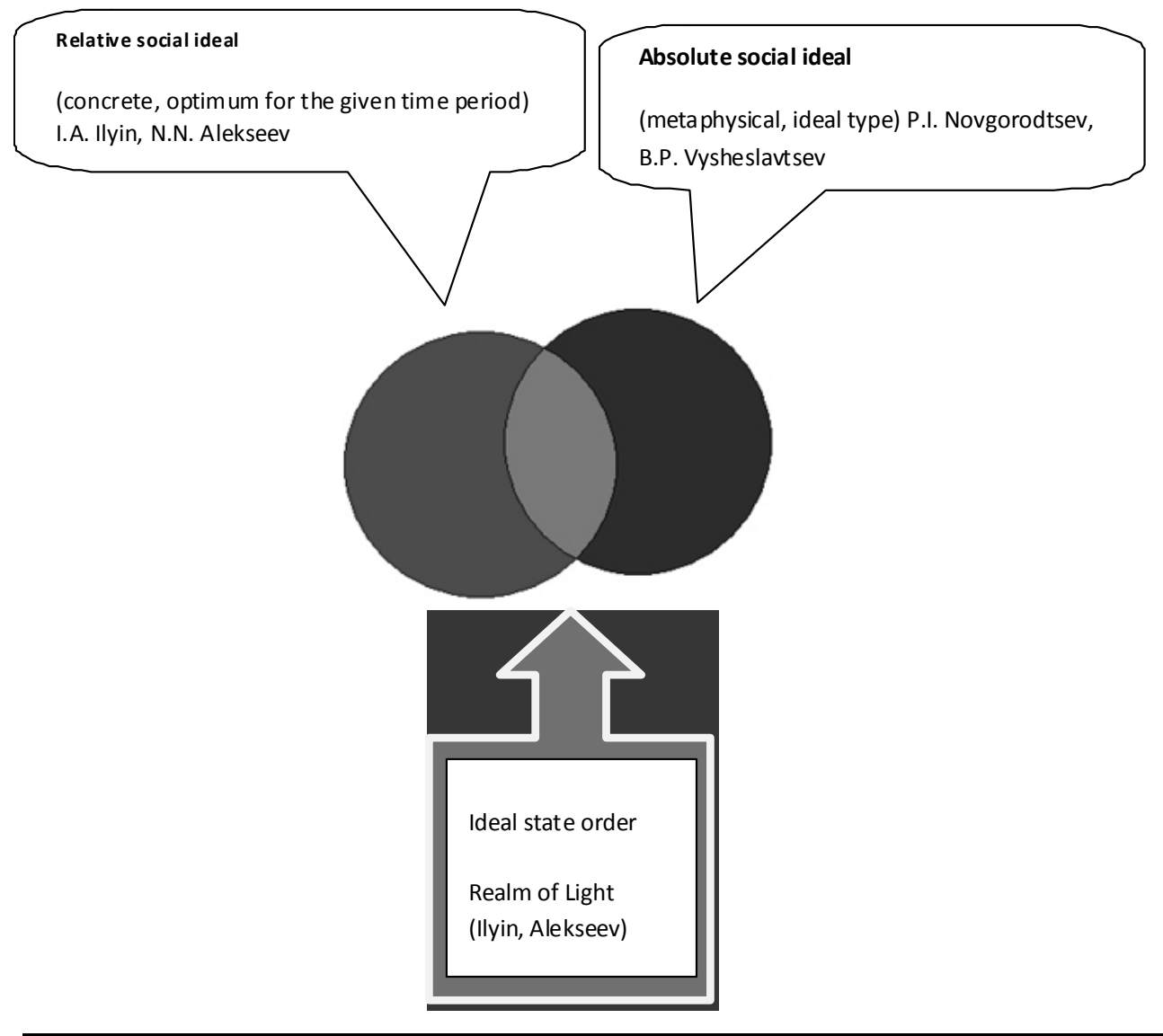

Fig. 1. CORRELATION OF CATEGORIES WITHIN THE MODEL

The following was found in the texts analysed

- Sixty most frequently repeating categories (designations) characterizing the social ideal (both relative and absolute);

- categories related to evolution process and approaching the relative ideal to the absolute one.

Twenty-nine categories characterizing the social ideal were found in the works by P. I. Novgorodtsev and B. P. Vysheslavtsev and thirty-one categories - in the works by I. A. Ilyin and N. N. Alekseev.

The categories that may be referred to economic and scientific dimensions are absent both in the works by P. I. Novgorodtsev and B. P. Vysheslavtsev and in the works by I. A. Ilyin and N. N. Alekseev. It gives rise to a suggestion that conceptions of the social 
ideal within P. I. Novgorodtsev's school comprise not all institutional dimensions that form the social structure.

Working with the material, it turned out that categories singled out and classified according to the above-mentioned dimensions cannot be divided into smaller units of content analysis. Categories intended to designate, name or illustrate the absolute social ideal (social ideal in general form) are given by the authors without any explanation or interpretation. They are represented abstractly and metaphysically in the authors' speculations, for example: Realm of Light, State of the Truth Found etc. We may come across such primary categories given without any comments and characterizing the social ideal not only in the texts of the authors under consideration. It happens because theoretical constructs of the four scholars intersect, or overlap, as we have mentioned earlier. They are distinguished only by the stress put while theorizing: some of them mostly developed an abstract absolute ideal, others - a more concrete one, political and relative (optimum for the given period).

E. g. , such category as the ideal state order ${ }^{4}$ belongs to the political dimension of the ideal, but at the same time it is the category of an absolute ideal and therefore is distinguished by abstractness, i. e. its content is not defined.

Most categories belonging to the political dimension of the social ideal, excluding one - theocracy, are synonyms per se and used by the authors metaphorically. In general, an ideal state, according to all the four thinkers, is a non-democratic, corporative and ideocratic state with a strong authority of law governed by a special social class - the leading class. It is a special political regime, traditional and appropriate for Russia only ${ }^{5}$.

Analysis of the social ideal parameters and related categories enabled to count percentage ratio of categories in the model (see Diagrams 1 and 1a).

In the works by by P. I. Novgorodtsev and B. P. Vysheslavtsev philosophical dimension accounts for the largest share (46\%), religious - for $21 \%$, aesthetical - for $17 \%$, political - for $17 \%$ and legal for $7 \%$. Thus most categories characterizing the social ideal belong

4 We may come across this category in the works by P. I. Novgorodtsev who mostly developed an absolute social ideal.

5 This wording of the political ideal claimed by the representatives of P. I. Novgorodtsev's school as an optimum one for Russia proves their ideology to be the Third Way ideology, recognized as a kind of fascism. 
PERCENTAGE RATIO OF CATEGORIES IN THE MODEL



DiAGRAM 1. SOCIAL IDEAL IN GENERAL FORM (ABSOLUTE IDEAL):

P. I. NOVGORODTSEV, B. P. VYSHESLAVTSEV



Diagram 1A. Political ideAl in GeNeral Form (RELATIVE IDEAL): I. A. Ilyin, N. N. AlekSEeV

to the most abstract dimensions, whereas political and legal dimensions which are supposed to contain more concrete categories count for little in comparison to others - just $24 \%$.

In the texts by I. A. Ilyin and N. N. Alekseev, who mostly developed a relative (political) ideal, political dimension accounts for $32 \%$ of categories in the model. Approximately the same share 
accounts for religious dimension - 31\%. Legal dimension accounts for $12 \%$ of categories, aesthetical - for $19 \%$ and philosophical - for $6 \%$. Thus, categories belonging to the most abstract dimensions account for the biggest share in the model. At the same time, the share of categories belonging to a religious dimension of the ideal is rather large. Political and legal dimensions account for $44 \%$ of the categories.

One can come to conclusions that the categories singled out in the texts created by all the four thinkers that characterize or designate the social ideal are mostly represented by abstract terms and belong to world outlook dimensions: religious, philosophical and aesthetical. Therefore, it would be reasonable to suppose that theoretical constructs of P. I. Novgorodtsev's school representatives, which belong to the social ideal, are not aimed at being put into practice (this supposition is to be checked at the second stage of the analysis).

In the course of the research there have been found several categories belonging to the process of transformation of the relative social ideal into the absolute one: Way to the highest perfection, Special path and Infinite improvement. These categories are also given without any explanation and are characterized by vague metaphoricity and abstractness.

In order to check up empirically the completeness of theoretical framework for creating the concept of the social ideal and to prove the existence of P. I. Novgorodtsev's school all-permeating categories have been singled out within the categorial model. These are words, word groups or phrases which characterize or name an ideal and are present in the works of all the four scholars. There are just seven categories like this: Special path, Soul of the nation, National unity, Law-governed state, Moral law and Infinite improvement.

The presence of these all-permeating categories as key categories in the texts of all the four authors may be regarded as a proof of unity of their theoretical position and of existence of the common school developing similar concepts.

At the first stage of text research, the supposition of identical theoretical framework of the basics of the social ideal concept by P. I. Novgorodtsev, B. P. Vysheslavtsev, I. A. Ilyin and N. N. Alekseev and of stylistic similarity of representation of this conceptwas verified and proved. Therefore, there are reasons to apply for the research of all the texts the methodological model that has been developed to define the ways of implementation of the social ideal. 
The main stress at this stage of the analysis should be put upon researching the texts of I. A. Ilyin and N. N. Alekseev as they have mostly developed the political (relative) ideal that, according to their intention, should have been implemented in the near-term historical perspective.

The texts of works by the authors under consideration have been studied fully using the above-mentioned methodology. As the number of texts analysed is rather great (24 articles and 41 monographs) it turns out impossible to demonstrate the analysis of each extract from all these texts. The analysis was performed according to the model of the social ideal taken from the works of P. I. Novgorodtsev's school representatives.

At each of the four research levels, identified in the methodological section, the required text extract, correlating to the particular element of this model, is quoted for demonstration purposes.

The first level of the research lets us draw the following conclusions: percentage module-wise distribution of text content is disproportionate. The greatest part of the text belongs to Thesis module $-68 \%$. Method and Goal modules together account for only 25\% (Method - 15\% and Goal - 10\%). Least represented in the distribution are Task module - 5\% and Example module - 2\% (see Diagram 2).



DIAGRAM 2. SPECIFIC WEIGHT OF VARIOUS ANALYTICAL CATEGORIES IN THE THEORETICAL TEXTS OF P. I. NOVGORODTSEV'S SCHOOL REPRESENTATIVES

Taking disproportional text distribution throughout key categories, metaphoricity and abstractness of their representation as well as minimum number of words belonging to Task, Goal and Example 
categories into account it may be supposed that the means of reaching the ideal remain hidden. Theoretical constructs are mostly statements or declarations of certain theses or categories.

Specific weight of Goal module accounts for only $10 \%$. Nevertheless considering this module is of primary importance for semantic and structural analysis, as it is impossible to start analysing goals without it.

The tasks in the text are represented by a number of declarations and phrases close to the theses in their meaning. Connections between the majority of tasks and methods of their solution are not traceable, which is demonstrated in the research.

Texts under analysis may be by convention divided into four groups according to their content (see Diagram 3).

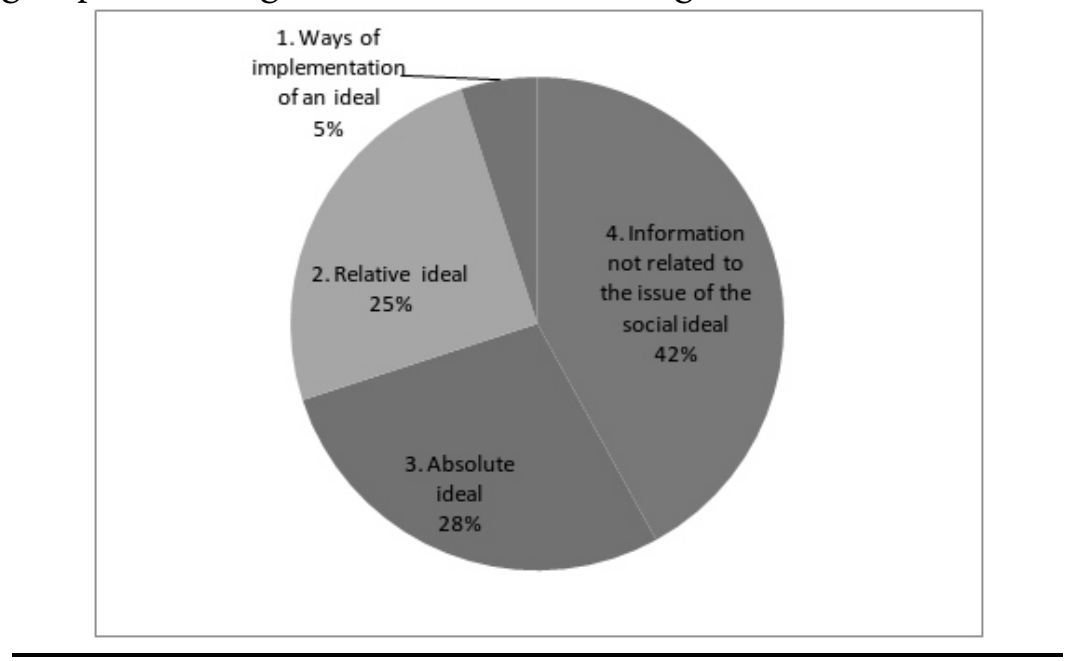

DIAGRAM 3. SPECIFIC WEIGHT OF EXTRACTS FROM ANALYZED TEXTS OF P. I. NOVGORODTSEV'S SCHOOL REPRESENTATIVES

The total number of sources under analysis is sixty-five: 24 articles and 41 monographs. The number of words in such texts makes approximately 46973550 .

Considering Diagram 3, part 1 - Ways of implementation of an ideal - is of particular interest. This is the part with the smallest volume, but the most important one for the analysis. Analysis results show that the authors pay little attention to the ways of implementation of an ideal. Moreover the authors offer only the most abstract and general ways of turning their ideas into reality. P. I. Novgorodtsev and B. P. Vysheslavtsev think it possible to implement the ideal by 
means of modernizing the state using existing state structure models that should be adapted to the Special path of Russia.

B. P. Vysheslavtsev, I. A. Ilyin and N. N. Alekseev stress the role of a special social class - the leading class. I. A. Ilyin and N. N. Alekseev developed in details the provisions of the leading class role in implementing their theories as well as stressed the necessity of Divine Providence to create the optimum state structure in Russia. I. A. Ilyin developed the concept of ranks according to which the elite plays the basic role while creating an ideal state. The ways of reaching the optimum state structure are strong power, evolution of legislative system, equality of freedoms, maintaining and particular attention to historical and national originality as well as mandatory following traditions while reforming state institutions. Thus, all ways of implementation of the ideal are only declarative and close to theses in their meaning.

Such is the completion of the first level of semantic and structural analysis in the course of which notional modules were singled out in the texts. Notional analysis of these modules is performed at the second level. Units of the analysis are words and word roots. The main principle of selecting the required words is their correlation with the complex model of the social ideal theory identified earlier (see Scheme 2).

One should bear in mind the presence of some inaccuracies in the obtained results caused by a very large volume of texts under analysis. For this reason, it turns out impossible to analyze the whole text corpus at the second stage of semantic and structural analysis. At this stage of the research analysis units will be selected only from one source - a monograph by N. N. Alekseev "Theory of state: Theoretical political science, state structure, state ideal" (1931).

The choice of this monograph is conditioned by the fact that it was issued during a later period of the author's work by which the social ideal concept had already taken its shape (see Scheme 2).

The number of words in the text under analysis makes 54600.30 words, most important for the research, were picked up in the course of selection process. They are repeated throughout the text, and therefore their quantity reaches 2184 . Selected words account for $4 \%$ of the text. The quantity of words on one page is about 260 . Thirty words belonging to the social ideal concept most frequently used and most frequently occurring in the text are given in Table 1. 




SCHEME 2. THEORY OF THE SOCIAL IDEAL BY P. I. NOVGORODTSEV'S SCHOOL

\begin{tabular}{|c|c|c|c|c|c|}
\hline & WORDS & AMOUNT IN THE TEXT & & WORDS & AMOUNT IN THE TEXT \\
\hline 1 & $\begin{array}{l}\text { Должен (должно) } \\
\text { / Must }\end{array}$ & 174 & 16 & Ocoбый / Special & 49 \\
\hline 2 & Будет / Will be & 163 & 17 & $\begin{array}{l}\text { Свят (ыня, ой) / } \\
\text { Sanctuary (saint) }\end{array}$ & 48 \\
\hline 3 & $\begin{array}{l}\text { Государство / } \\
\text { State }\end{array}$ & 160 & 18 & $\begin{array}{l}\text { Достой (ный, oe, } \\
\text { ство) / Worthy } \\
\text { (worthiness) }\end{array}$ & 47 \\
\hline 4 & Строй / Regime & 142 & 19 & Наш (наше) / Our & 45 \\
\hline 5 & Путь / Path & 121 & 20 & $\begin{array}{l}\text { Мир / Word } \\
\text { (Peace) }\end{array}$ & 44 \\
\hline
\end{tabular}

TABLE 1: MOST FREQUENTLY OCCURRING WORDS BELONGING TO THE CATEGORY OF THE SOCIAL IDEAL 


\begin{tabular}{|c|c|c|c|c|c|}
\hline 6 & Идея / Idea & 119 & 21 & $\begin{array}{l}\text { Вселен (ский) / } \\
\text { Universal }\end{array}$ & 43 \\
\hline 7 & Закон / Law & 108 & 22 & $\begin{array}{l}\text { Вечны (ый, ая, } \\
\text { oe, сть) / Eternal } \\
\text { (eternity) }\end{array}$ & 42 \\
\hline 8 & $\begin{array}{l}\text { Право (вой) / } \\
\text { Right(ful) }\end{array}$ & 96 & 23 & $\begin{array}{l}\text { Истина (ность, } \\
\text { ый) / Truth } \\
\text { (true) }\end{array}$ & 41 \\
\hline 9 & $\begin{array}{l}\text { Корпорация (кор- } \\
\text { поративный) / } \\
\text { Corporation } \\
\text { (corporate) }\end{array}$ & 77 & 24 & $\begin{array}{l}\text { обновление(ый, } \\
\text { ость) / Renewal } \\
\text { (renewed) }\end{array}$ & 40 \\
\hline 10 & $\begin{array}{l}\text { Совершенство } \\
\text { (ный, ые) / } \\
\text { Perfection (perfect) }\end{array}$ & 75 & 25 & $\begin{array}{l}\text { Русский (oe) / } \\
\text { Russian }\end{array}$ & 38 \\
\hline 11 & Судьठа / Fate & 74 & 26 & $\begin{array}{l}\text { Народ (ый, ое) / } \\
\text { People (n. , adj. ) }\end{array}$ & 37 \\
\hline 12 & Высший / Higher & 71 & 27 & $\begin{array}{l}\text { Новый (ая, ое) / } \\
\text { New }\end{array}$ & 36 \\
\hline 13 & $\begin{array}{l}\text { Бесконечный (ठес- } \\
\text { конечно) / } \\
\text { Endless(ly) }\end{array}$ & 67 & 28 & $\begin{array}{l}\text { Справедливый } \\
\text { (oе, ая) / Just }\end{array}$ & 36 \\
\hline 14 & Власть / Power & 66 & 29 & $\begin{array}{l}\text { обязан (ный, } \\
\text { ность) / Obliged } \\
\text { (obligation) }\end{array}$ & 33 \\
\hline 15 & $\begin{array}{l}\text { Нравствен } \\
\text { (ный,ность) / } \\
\text { Moral(ity) }\end{array}$ & 56 & 30 & $\begin{array}{l}\text { Духовный / } \\
\text { Spiritual }\end{array}$ & 33 \\
\hline
\end{tabular}

TABLE 1: MOST FREQUENTLY OCCURRING WORDS BELONGING TO THE CATEGORY OF THE SOCIAL IDEAL

Most selected words having the key meaning - path, idea, fate, endless, special, higher, universal, eternal, truth, renewal, spiritual - are of metaphysical, religious and philosophical character. These are the most general and vague notions which make it impossible to understand how exactly the project of an ideal state should be implemented as well as what is an ideal state. Generally speaking, the analysis made it possible to find out that a distinct and well developed terminology is absent in the texts. It gives rise to difficulties while defining the meaning of many key words. 
Such words as должен (тust) and бyдеm (will be) (the most frequent ones - 337 times) are used as synonyms in the text and are most often accompanied by such units of analysis as cmpoŭ (regime), nраво (right), государство (state), идея (idea) and власть (power).

It should be emphasized that words with negative meaning such as нет (nо), не (not), невозможно (impossible) are not used in the text with the words бydem (will be) and должен (тust). It is indicative of the declarative character of the statements. The author neither takes into account nor estimates the negative consequences of implementation of the social ideal. The author uses pairs of words containing such units of analysis as должкен (must) and бydem (will be) in their standard meaning. If clear instructions about the form and the ways of building a certain state are absent in the text theoretical constructs remain mere ideological declarations.

On compiling the table of key words describing the social ideal most frequently used in the text and on singling out modules in line with the research program, the researcher goes on to the third level of semantic and structural analysis (notional part).

The author gives as an example the analysis of the part of texts named in the model Ways of implementation of an ideal. The following text categories mostly correspond to this part: Task, Method and Goal.

The goals are not clearly formulated in the texts under analysis, but they may be revealed upon a closer view. The researcher singled out two goals from the analysed sources:

1) To establish the optimum and the most suitable political regime in Russia.

2) To approach as near as possible to the absolute social ideal by reaching the first goal (establishing the most ideal regime for the given epoch).

The above-mentioned goals correlate to the tasks proposed by the authors for reaching them. Goals in the texts are not numerous either -transformation of state structure, weakening of power relationships in a state and strengthening the authority of law. An obvious contradiction results from the above-mentioned: How can weakening of power relationships be combined with strengthening the authority of law? As a rule, the latter results in strengthening political regime and, as a consequence, in centralization of power.

The works by I. A. Ilyin name in the most concrete way the exact changes of the state regime to be made. In his opinion a state is like 
a corporation with a hierarchy built from below on the one hand and like an institution with the opposite strategy of building a hierarchy on the other hand (Ilyin, 1991, p. 22). He thinks these two components, corporativity and organization from above, should be balanced, but the latter one dominating. Thus, the changes named as the first task consist in harmonizing the two directions of state regime formation (from above and from below). Other representatives of this school speak merely of state regime transformation without giving any clear explanations.

Solving the task defined as weakening the power relationships is supposed to approach the state to the absolute social ideal (a powerless organization). The method identified as upbringing an independent personality by means of patriarchal traditions and values correlates to this task. B. P. Vysheslavtsev in his works draws a parallel between family and state considering the relationships in both institutions to be identical: a state is a kind ofextrapolation of family model (Vysheslavtsev, 1994, p. 212]. According to B. P. Vysheslavtsev statehood develops similarly: starting from "childhood" characterized by strict absolutism and gradually moving on to "adulthood" characterized by more liberal forms of social relationships with more freedoms for citizens.

The next method related to the tasks of weakening the power relationships and strengthening the power of law is the formation and establishing the power of the leading class, a kind of aristocracy, which is an achievement on the way to the absolute social ideal (powerless organization). The leading class is to be formed of the best-selected citizens (superiority criteria are not given). According to the theorists' intent, its formation should have been accompanied by rising legal awareness and overcoming such imperfections of a state as intense rivalry during the race for power and arguments between the social strata.

It should be stressed that highlighting the above-mentioned tasks was a result of the analysis. These tasks corresponding to Thesis analytical category in terms of their meaning were singled out from the authors' declarative statements. Methods proposed for their solution are also expressed with the help of constructions expressing obligation and turn out impossible to be implemented. A number of contradictions is found between the tasks and the proposed methods for their solutions. E. g. , it is unclear why the appearance of the ruling elite class - the leading class - is considered an achievement on the way to the absolute ideal, which pre- 
supposes social equality. It is also unclear how strengthening the authority of law can be combined with the weakening of power relationships. The authors fail to explain why a particular method is the most suitable one for reaching the goal. Words used in the text characterizing goals, tasks and methods bring no functional sense.

The concept developed by P. I. Novgorodtsev's school representatives is just one of utopian ideologies that is naturally impossible to implement.

Going on to the fourth level of semantic and structural analysis it should be stressed that the part of text identified as Ways of implementation of the social ideal on Diagram 3 and analysed on the third level correlates to the notional module that may be called the module of practical implementation of the social ideal theory.

This is the most developed module, singled out during semantic analysis of the texts.

One can but conventionally speak of other notional modules in the texts than the one of practical implementation of the social ideal theory (the texts contain abstract models formed while analysing the authors' theoretical speculations, and the issue of implementing the social ideal is represented in declarative form only). It is for this reason that the specific weight of Thesis category in the texts, denoting a statement or a definition given without any substantiation and verification, is so considerable (68\%). Parts of texts marked Relative ideal and Absolute ideal on Diagram 3 as are almost completely formed of such declarative statements not substantiated by the authors and not represented by them as a coherent integral system. Apart from the thesis attempts were made to single out such categories in the texts defined in the research program as Subject and Topic. Analytical categories marked as Goal as well as related Task and Method categories required to solve the task have not been found in the text ${ }^{6}$.

Thus speaking about connections between the modules it should be stressed that singling out modules, except the one containing the ways of the social ideal implementation, is conditional and is realized at the level of an ideal model.

6 As has been mentioned earlier, components of Goal tax on may be connected with the thesis. The difference between a goal and a thesis is that a goal is aimed at performing a certain action. 
Having analysed the contents of parts 2 and 3 of the texts under analysis (see Diagram 3) one can single out the following sensebearing modules:

1) Notional module (corresponding to the text extracts considering the structure of the social ideal, e. g. ratio of the absolute and the relative in the structure of an ideal).

2) Axiological module (corresponding to the text extracts considering axiological aspect of the social ideal theory: moral and religious values embedded by the authors into the structure of the political ideal, as well as nationalistic and humanistic categories).

Let us consider the modular structure of text extracts by P. I. Novgorodtsev, B. P. Vysheslavtsev, I. A. Ilyin and N. N. Alekseev belonging to theoretical concept of the social ideal theory developed by these authors. In total three modules may be singled out two of which are just conditional, having no goals and represented by a theoretical text of metaphysical nature or by a declaration. The first module belonging to the implementation of the social ideal theory is loosely connected with the other two. Moreover it is not sufficiently developed by the authors: the goals are not clearly defined, not many tasks are mutually contradicting (on the one hand the weakening of power relationships is considered necessary, on the other hand - the strengthening of the authority of law). There are contradictions between the tasks and the methods of their solution - it is unclear why appearance of a new aristocracy, the leading class, is a sign of progress and is to be the factor approaching the state to the absolute social ideal (powerless organization). A number of declarative theses also represents this module. Methods and ways of implementing the social ideal are just abstract structures. Thus, it can be said that a module has no functional meaning.

Everything mentioned above testifies that all the three modules singled out in the course of semantic and structural analysis are a mere set of theses containing unproved statements.

Results obtained in the course of content analysis make us come to the following conclusions:

- On the basis of an empirical research existence of a unified P. I. Novgorodtsev's school represented by its disciples - B. P. Vysheslavtsev, N. N. Alekseev and I. A. Ilyin - is substantiated; 
- Representatives of this school have been developing the concept of the social ideal characterized by similar conceptual frameworks;

This concept turned out to be weakly substantiated theoretically, internally contradictory and principally impossible to be implemented;

- The concept of the social ideal developed by representatives of P. I. Novgorodtsev's school is an exceptionally ideological abstract scheme having no relation towards social practice.

REFERENCES Holsti, O. R. (1969). Content analysis for the social sciences and humanities. Reading, MA: Addison-Wesley.

Alekseev, N. N. (1931). Teoriya gosudarstva: Teoreticheskoe gosudarstvovedenie, gosudarstvennoe ustroystvo, gosudarstvennyi ideal. - Prague.

Vysheslavtsev, B. P. (1994). Vechnoe v russkoy filosofii. Moscow: Res publika. Vysheslavtsev, B. P. (1994). Etika preobrazhennogo Erosa. Moscow: Res publika.

Gotlib, A. (2005). Vvedenie v sotsiologicheskoe issledovanie. Moscow: Flynta. Dridze, T. M. (1984). Tekstovaya deyatelnost v structure sotsialnoy kommunikatsii. Moscow: Nauka.

Ilyin, I. A. (1991). O monarkhii i respublike. Voprosy filosofii, Vol. 5.

Orlova, E. A. (2013). «Modern kak kulturnyistil». Observatoriya kultury, Vol. 4, $4-23$.

Eisenstadt, S. (1999). Revolyutsiya i preobrazovanie obshchestv. Sravnitelnoe izuchenie tsivilizatsiy. - Moscow. 
ПЈОТР ЦАРКОВ

РУСКИ ИСТРАЖИВАЧКИ ИНСТИТУТ

ЗА КУЛТУРНО И ПРИРОДНО НАСЛЕЪЕ

МОСКВА

РЕЗИМЕ

ОСОБИНЕ МЕТОДОЛОГИЈЕ СОЦИОЛОШКЕ АНАЛИЗЕ

Овај чланак разматра искуство примене социолошке методе анализе садржаја и информационо-циљне анализе на учење наслеђе представника предреволуционарне руске друштвене концепције (П. И. Новгороцев, Б. П. Вишеславцев, И. А. Иљин и Н. Н. Алексејев). Аутор примењује методолошки модел семантичке и структурне анализе на основу комбинације класичне квалитативне и квантитативне анализе садржаја и информационо-циљне анализе.

КључнЕ РЕчи: Анализа садржаја, методолошки модел семантичка анализа, структурална анализа. 